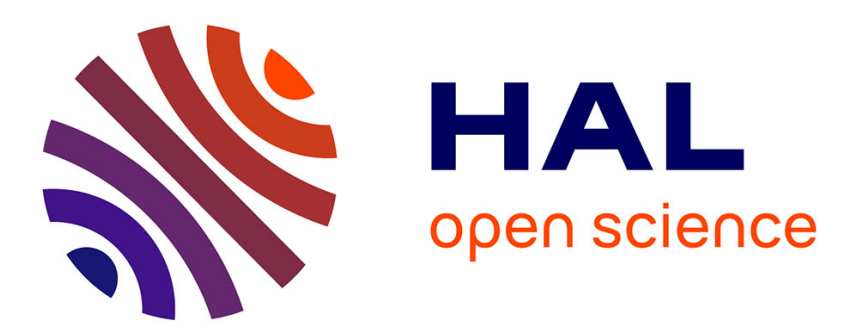

\title{
The phasing out of EU agricultural export subsidies : impacts of TWO management schemes
}

\author{
Alexandre Gohin, Patrice Gautier
}

\section{To cite this version:}

Alexandre Gohin, Patrice Gautier. The phasing out of EU agricultural export subsidies : impacts of TWO management schemes. 2008. hal-01931642

\section{HAL Id: hal-01931642 \\ https://hal.science/hal-01931642}

Preprint submitted on 22 Nov 2018

HAL is a multi-disciplinary open access archive for the deposit and dissemination of scientific research documents, whether they are published or not. The documents may come from teaching and research institutions in France or abroad, or from public or private research centers.
L'archive ouverte pluridisciplinaire HAL, est destinée au dépôt et à la diffusion de documents scientifiques de niveau recherche, publiés ou non, émanant des établissements d'enseignement et de recherche français ou étrangers, des laboratoires publics ou privés. 


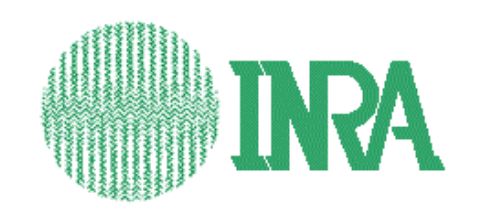

Institut National de la recherche Agronomique

Unité d'Economie et Sociologie Rurales

4 Allée Adolphe Bobierre, CS 61103

F 35011 Rennes Cedex

Tél. (33) 02234853 82/53 88 - Fax (33) 0223485380

http://www.rennes.inra.fr/economie/index.htm

\section{The phasing out of EU agricultural export subsidies: \\ Impacts of two management schemes}

June 2003

Working Paper 03-06 


\section{The phasing out of EU agricultural export subsidies: \\ Impacts of two management schemes}

Alexandre GOHIN and Patrice GAUTIER

INRA - ESR Rennes

Paper presented at the International Conference "Agricultural Policy Reform and the WTO:

Where are we heading?", Capri (Italy), June 23-26, 2003.

\section{Corresponding address}

Alexandre GOHIN

INRA - Unité ESR

4 Allée Bobierre, CS 61103

35011 Rennes Cedex, France

Email: Gohin@roazhon.inra.fr 


\begin{abstract}
The present round of multilateral trade negotiations at the World Trade Organisation is likely to put an end to European export subsidies on agricultural and food products. This paper then attempts to evaluate such a policy scenario in isolation from other negotiations chapters. The main contribution of this paper is to compare two management schemes of this scenario on the European Union economy. The first one has confidence in the equilibrium role of market prices while the second one favours a supply management approach. After a theoretical analysis of advantages and drawbacks of both schemes, we conduct an empirical analysis using a computable general equilibrium model focused on the European agricultural and food sectors. Our empirical results show that the phasing out of agricultural export subsidies will have huge effects on the dairy sector and more limited impacts on arable crops and meat sectors, whatever the management scheme is. Our empirical analysis also reveals that the choice of a management scheme has a substantial bearing on sectoral welfare effects. The relevance of an European agricultural policy relying on effective supply management is finally discussed.
\end{abstract}

Keywords: WTO, CAP, Export subsidies, Supply Management

JEL classification: Q11, Q18, D58

\title{
Résumé
}

Les présentes négociations commerciales multilatérales conduites à l'Organisation Mondiale du Commerce vont probablement conduire à une suppression des subventions directes aux exportations de produits agricoles et agroalimentaires. Cet article propose une évaluation au niveau européen des impacts économiques d'un tel scénario. La contribution majeure de cet article est de comparer deux modes de gestion de cette suppression. Le premier mode suppose un ajustement au choc par une nouvelle baisse des prix de soutien des produits agricoles tandis que le second mode considère un renforcement des mesures de contrôle de l'offre domestique. Après une comparaison théorique de ces deux modes de gestion, l'article fournit une évaluation empirique s'appuyant sur une modélisation en équilibre général calculable. Les résultats montrent clairement que la suppression des exportations subventionnées affecte très fortement la filière laitière et ce quel que soit le mode de gestion. Ils montrent surtout que le choix d'un mode de gestion a des conséquences substantielles sur les gains et pertes des différents agents économiques. Les implications politiques, notamment en terme d'évolution de la Politique Agricole Commune, sont finalement discutées.

Mots clé: OMC, PAC, Subventions aux exportations, Contrôle de l'offre

Classification JEL: Q11, Q18, D58 


\title{
The phasing out of EU agricultural export subsidies: Impacts of two management schemes
}

\author{
Alexandre GOHIN, Patrice GAUTIER
}

\section{Introduction}

World Trade Organisation (WTO) members are now truly engaged in a new round of multilateral trade negotiations, often referred as the Millenium Round (MR) or the Doha Development Agenda (DDA). The final outcome of the MR is at present highly uncertain, notably due to the excessive complexity of the agricultural dossier. Agricultural negotiations focus on three main areas: market access, domestic support and export competition. There exist many economic analyses showing that progress on the market access chapter may be difficult to obtain because further liberalisation here may be detrimental for developing countries (mainly via lost benefits from preferential trade agreements) (for instance, François et al., 2003). In the same vein, available economic analyses tend to conclude that further liberalisation of "domestic support" instruments may lead to very limited benefits, if any (for instance, Dimaranan et al., 2003). On the other hand, the negotiations on the third area seem to be less difficult to conduct as there is only one major user of export subsidies (the European Union, EU) and accordingly, impacts for each WTO member are more easily identified. Some observers then believe that these negotiations with the large number of players with diverse and conflicting interests are likely to evolve towards a modest outcome characterised by only new firm commitments on export subsidies (for instance, Vanzetti and Peters, 2003).

According to their position papers, the vast majority of WTO members are calling for outright elimination of export subsidies. Leading countries for the complete removal of these instruments include the members of the Cairns Group and the USA. As expected, the EU does not (officially) support this proposal. Instead, the EU position paper of January 2003 proposes an average $45 \%$ cut in the level of export subsidies and requests flexibility in the implementation of this constraint. The analysis of the evolution of EU export subsidies may help to understand this proposal (see figure 1). Since the beginning of the 1990s, one can observe a tendency towards the reduction of EU total export subsidies. They decrease in average by nearly $10 \%$ annually but this reduction is unequally distributed between agricultural products. Export subsidies on dairy and sugar products have slightly decreased compared to export subsidies on arable crops or meat products. The two reforms of the Common Agricultural Policy (CAP) (the "MacSharry" of 1992 and the "Agenda 2000" of 1999), with reductions of market price support compensated by increasing direct payments, clearly have positively contributed to this phenomenon. It is still too early to perceive the full effects of the last reform but it seems not unlikely that export subsidies continue to prevail in the near future, at least on dairy and sugar products. In a general way, economic analysis of the Agenda 2000 CAP reform support this view. For instance, Van Meijl and Von Tongeren (2002) argue that they will remain significant export subsidies on dairy and sugar products while small export subsidies 
on other products after Agenda 2000. ${ }^{1}$ They furthermore underline that further adjustments of the CAP are inevitable in case of new international commitments on export subsidies. The " $45 \%$ " proposal of the EU may thus be viewed as a first negotiation position which minimizes CAP adjustments and still represents an offer at the WTO. ${ }^{2}$

Given this political context, we believe that a complete removal of EU export subsidies on agricultural and food products is a likely scenario. In fact, several quantitative evaluations of such scenario have already been performed. They generally focus on market effects of this policy experiment and rarely discuss effects on agents' welfare. Table 1 shows selected results from published studies. Most of them find that the phasing out of European agricultural export subsidies, after the full implementation of the Agenda 2000 CAP reform, will lead to notable reductions of domestic prices and will have moderate impacts on world prices. The impacts on EU exports will all be negative except for wheat due to cross-market effects. However, the magnitudes of these effects differ substantially across studies. As an example, the reduction of the domestic price of soft wheat ranges between $0 \%$ and $8.6 \%$. It is well recognised that several modelling factors have a substantial bearing upon model outcomes. For example, the OECD and USDA analyses highlight the sensitive issue of exchange rate assumptions. On the other hand, one common feature of all these evaluations concerns the management scheme of the removal of export subsidies. All assume that domestic prices are allowed to adjust downwards in order to restore market equilibriums. Other things being equal, these price reductions stimulate domestic demands and reduce domestic supplies, so that export supplies contract. Without any compensation in the guise of new or increased direct payments, this necessarily leads to a decrease of farmers profit, an increase of domestic consumer surplus and a reduction of public expenditures.

Our main purpose in this paper is to contribute to this literature on the evaluation of the phasing out of agricultural export subsidies by comparing the impacts of two alternative management schemes. The first scheme, hereafter referred as the price management scheme, assumes like previous analyses an adjustment of domestic prices to restore market equilibriums. The levels of other CAP instruments are unchanged in this case. In contrast, the second scheme, hereafter referred as the quantity management scheme, relies on the strengthening of supply control instruments. The main Common Market Organisations (CMOs) of the CAP involve instruments designed to regulate domestic supply of agricultural and food products. The most evident examples are the production quotas in the dairy and sugar CMOs. As far as the arable crop CMO is concerned, one must be aware that the land set-aside scheme restricts cultivated land and, by way of consequence, the domestic supply of arable crops. The beef CMO also includes supply control measures, mainly through animal density limits for direct payments. Therefore, the political tools are already present to impose a greater control on domestic supplies and thus to reduce export supplies, other than through price reductions.

\footnotetext{
${ }^{1}$ According to these authors, the export subsidies on feed grains are heavily dependent on world market conditions.

${ }^{2}$ At this stage, it is worth stressing that, since July 2002, there are intensive debates in the EU about a new reform of the CAP. The European Commission (EC) motivates its Mid-Term Review (MTR) proposals on internal considerations (mainly efficiency and multifunctionality issues) and argues that they are not imposed by WTO negotiations. Then our understanding is that the EC can not politically adopt right away a position in favour of the phasing out of export subsidies, because it requires a new CAP reform. A more detailed analysis of interactions between the two dossiers is available in Guyomard and LeBris (2003).
} 
Evaluating the impacts of the quantity management scheme may at first sight appear not relevant, as the CAP evolves since 1992 towards a re-instrumentation of income support in favour of direct payments and to the detriment of market price support. Moreover, current proposals of the EC on the Mid Term Review (MTR), if adopted, will make this re-instrumentation more pronounced. Despite this evolution, we are of the opinion that this evaluation is valuable for the following reasons. Firstly, some EU members are actually reluctant to the MTR proposals, notably the reduction of intervention prices. Secondly, main organisations representing interests of EU farmers are also opposed to new price reductions and furthermore they argue that supply management should be part of the future EU agricultural policy. Thirdly, the quantity management system may have the support of some EU institutions, like the European Court of Auditors. Fourthly, this strategy can also favour net exporters in the Rest of the World (RoW) because it provides support to the world price of agricultural and food products (for instance, FAPRI, 2002 on the arable crop CMO). Therefore, there potentially exist some supporters of the quantity management scheme and our comparative analysis can be viewed as a contribution to the debate about what future for the CAP.

Our numerical assessment of the two management schemes is conducted with a recently built Computable General Equilibrium (CGE) model focused on the EU agricultural and food sectors. This CGE model offers a fine representation of CAP instruments and therefore is well designed to our objective in this paper. Moreover, by its very nature, this modelling framework allows us to evaluate the impacts of the two schemes on market variables (supply, demand, price, export, ...) as well as on agents welfare (consumer surplus, farm profits, taxpayer contribution, ...). Hence we can identify winners and losers in each case. Before embarking on this empirical analysis, we first turn to a review of the theoretical advantages and drawbacks of the two management schemes.

\section{Price versus Quantity Management: A Theoretical Analysis}

\section{Analytical Framework}

The main consequences of the two management schemes of the phasing out of agricultural export subsidies are set out with a graphical analysis (see figure 2). To keep this analysis manageable, we first consider a partial equilibrium framework with only one agricultural market and where the world price $(P W)$ is assumed to be exogenous (small country assumption). This initial framework is very stylised but still permits to identify some critical trade-offs.

We assume that two agricultural policy instruments are initially in place: a market price support system at price

$P$ and a production quota system at level $\bar{Y}$. The market price support system is in practice ensured by the imposition of a tariff (at least equal to the difference between the guaranteed price and the world price) which prevents imports and by the granting of export subsidies which allows to dispose excess domestic supply on the world market. The production quota system is assumed to be active in this initial situation, as domestic producers want to produce more than the quota level at the guaranteed price. Dual to this quantity constraint is the unit quota rent, defined by the difference between the guaranteed price and the shadow price of the quota (i.e. the price that would induce to freely produce at the quota level). This unit quota rent is given by the distance de on figure 2. In this initial situation, the domestic supply is greater than the domestic demand (denoted by $D_{0}$ ) and 
the export level is given by the difference between these two quantities. Export subsidies then amount to the area $c d f g$. Producer profit is equal to the area $a P_{O} d e$ and consumer surplus to the area $\mathrm{b} P_{O} c$. Total welfare is usually measured as the sum of these two welfare measures, less public expenditures. It is here given by the difference between the area $a b c g j$ and the area jef. At this stage, one can check that this initial welfare is lower than in the free trade case, but greater than in the situation with the sole market price support system. In other words, the production quota system reduces the distortions in production due to the market price support regime but is only a second-best solution.

In this setting, let's first consider the price management scheme where policy makers allow the domestic price to adjust downward in order to fit domestic supply to unsubsidised total demand. The resulting equilibrium is then characterised by the new domestic price $P$ which is lower than the initial guaranteed price. This price reduction stimulates domestic demand to the level $D_{1}$ and, in the same time, reduces production incentives. We observe that, at the end of the day, domestic production is equal to domestic demand and that the quota level is no longer binding. In other words, the price reduction is sufficient to put at zero the quota rent. The production quota system is therefore not active whereas the market price support system operates with a new guaranteed price, lower than the initial one. There still exists one tariff which prevents imports to enter into the domestic market. If there is no compensation in the form of direct payments, producer profit becomes equal to the area $a P h$. It is therefore lower than the initial one due to both price and supply reductions; the profit reduction is equal to the area $P P_{0} d e h$. On the other hand, consumer surplus increases by the area $P P_{0} c h$, thanks to the price reduction and the consequent increase in domestic demand. Finally, public expenditures become zero. Total welfare is then equal to the area $a b h$ and greater than the initial one by the area $c g f e h$. This welfare gain results from the reductions of distortions at domestic production and domestic demand sides. The resulting welfare is still lower than in the free trade case, as we assume that there remains one tariff which is at least equal to the difference between the new equilibrium price and the unchanged world price.

Let's now consider the quantity management scheme. The reduction of total demand following the phasing out of export subsidies may be accompanied by an exogenous reduction of domestic production. For simplicity, we assume that the policy maker is able to fix the production quota at the initial level of domestic demand ( $\left.D_{0}\right)$. Accordingly, the resulting equilibrium is given by a domestic price unchanged $\left(P_{O}\right)$ and domestic supply equals domestic demand, so that exports are again zero. The production quota system becomes more binding, as suggests the increased quota rent which reaches the $c k$ distance on figure 2. The market price support system is also active, insofar as tariffs are still required to prevent imports. The welfare effects of the quantity management scheme are completely different from those obtained with the price scheme. Consumers surplus is stable relative to the initial situation, because the domestic price is unchanged. Producers profit decreases by the area $c d e k$, only due to a volume effect. Public expenditures are still zero. As a whole, it is however not possible to determine if there is a welfare gain or loss. Total welfare changes by the difference between the area efj and $g j k$. This ambiguity can be explained as follows. The distortions in domestic consumption are unchanged with the quantity management scheme. The distortions in domestic production are, on one side, reduced thanks to the volume effect but, on another side, a new distortion appears. The shadow price at the new quota level is lower than the world price. Accordingly, some producers not only want to produce more given domestic price but also want to 
produce more given this world price. The total effect on the distortions in domestic production is therefore ambiguous.

We are now in a good position to compare the two management schemes. This is done according to two criteria. We first examine their economic efficiency before discussing their acceptability at the WTO.

\section{Economic efficiency}

In the static, partial equilibrium framework outlined above, there is no doubt that the price management scheme is more efficient than the quantity management scheme. The gain in total welfare is represented by the area $c h k$. One can note at this stage that both schemes lead to autarky and that this area corresponds to the welfare loss of imposing a production quota at level $D_{0}$ in a closed economy. ${ }^{3}$ There is also no doubt that the price management scheme is preferred by consumers, their surplus gain being equivalent to the area $P_{O} P h c$. Both schemes remove export subsidies; thus taxpayers are indifferent between them. As far as the interest of producers is concerned, we cannot provide a clear-cut conclusion. The difference in profit between the quantity and the price schemes is given by the area $P O P$ ic less the area $i h k$. The trade-off facing producers is therefore between the couple "high price; low quantity" and the couple "low price; high quantity". It mainly depends on the production technologies and the structure of production costs. For instance, if the price elasticity of supply is very low, the positive volume effect in the price scheme can be modest and thus the producer will prefer the quantity management scheme. Therefore, if the political objective is to minimize the welfare loss of the producer following the phasing out of export subsidies, this first theoretical analysis cannot provide a definitive answer. It may be in the interest of producers, as they generally ask for, to strengthen the supply management instruments.

At this stage, some qualifications are in order. Firstly, our demonstration is very simplified and a much more rigorous presentation of the welfare effects of different agricultural policy instruments, under different price elasticities of supply and demand, is available in Gardner (1983). Our contribution here is to adapt the general results detailed in this paper to our specific case of the removal of export subsidies. By the way, we note that many papers took advantages of Gardner's results. ${ }^{4}$ For instance, de Gorter and Meilke (1989) determine the optimal policy instrument in order to achieve a given welfare of EU arable crop farmers and found that a policy based on production quotas is generally the most efficient. Secondly, our analysis is conducted assuming that only two policy instruments are available: the market price support system and the production quota. Extending this analysis by taking into account direct payments to primary factors will naturally affect the result, for example if we assume that compensation of profit loss by new direct payments is possible. The critical issue is to know whether the support of farm incomes by taxpayers is more efficient than the support by consumers. If one rests on the static, perfect competition, partial equilibrium framework used so far and considers that lump sum direct payments exist, then the compensation for the loss of producer income is no longer a real issue and the price management scheme is then better for all economic agents than the quantity management scheme.

This last result depends on several assumptions that deserve, at the very least, some new discussions. We successively consider, in a very brief and intuitive manner, some implications of three maintained hypotheses:

\footnotetext{
${ }^{3}$ Equivalently of imposing a unit tax of amount $c k$, with the redistribution of tax product to the producer.

${ }^{4}$ Many are quoted in Bullock and Salhofer (2003) and Alston and James (2003).
} 
static, perfect competition and partial equilibrium. ${ }^{5}$ The introduction of dynamic elements makes the comparison between the two management schemes even more complex. On the one hand, it is well recognised that production quotas hamper structural changes and thus generate inefficiencies. Moreover, gains from technical changes are not transmitted to the "market" and thus make reforms more difficult to finalise. On the other hand, farmers expectations about output prices are not as much critical in the quantity management scheme (with a binding level of production quota) as they are in the price management scheme. Secondly, the perfect competition is a widely adopted assumption, mainly by convenience. However, if one thinks that food processing and/or food retailing industries are not perfectly competitive, then the efficiency ranking of the two management schemes can again be altered. For instance, if scale economies are present and these industries adopt average pricing, therefore the quantity management scheme may be less efficient as it reduces supply of raw materials for these industries. On the other hand, if these industries as a whole have an oligopsony power, then the price reductions resulting from the price management schemes may not reach the final consumer but may result in an increase of rents in these industries. Finally, the partial equilibrium analysis neglects the various effects in the rest of the economy. On the one hand, it does not consider the induced effects on other agricultural and food markets. If the quantity management scheme is applied to only one agricultural sector, there will be some reallocations of primary factors to other production activities and consequently the issue may only be displaced to another sectors. On the other hand, this partial equilibrium analysis focuses on the market effects of agriculture and food sectors and omits their non-market effects. In other words, the multi-functional role of agriculture was ignored so far. The design of an optimal policy for promoting the positive roles of agricultural activities on rural development and environment is really complex, notably due to the difficulty to evaluate the transaction costs. In that respect, production quotas may have a role as they allow some farmers to stay in activity in some less favourable regions.

To sum up this discussion, the superiority of one management scheme in terms of economic efficiency is very difficult to establish theoretically. Excluding the traditional static, perfect competition, partial equilibrium analytical framework where lump sum transfers are assumed to exist, it seems possible to always find theoretical arguments in favour of one management scheme.

\section{WTO acceptability}

The comparison of the two management schemes in terms of acceptability at the WTO is much easier, because the focus is on market effects (price, production, demand, exports and imports) and not on the welfare effects discussed in the previous paragraph. The comparison of market effects is much less dependent of the analytical framework adopted (static/dynamic, ...) insofar as the quantity management scheme will always lead to higher domestic price than the price management scheme. For simplicity, we return to our initial analytical framework to discuss this point.

The acceptability of the two management schemes at the WTO is assessed in light of the three main areas of the agricultural negotiations. As far as the export competition chapter is concerned, both management schemes are designed such as to remove export subsidies and naturally they are both acceptable from WTO partners of the EU.

\footnotetext{
${ }^{5}$ More elements can be found in Gohin et al. (1999).
} 
On the domestic support dossier, we first recall the existing rules. Domestic support policies are henceforth placed in "boxes" according to their impact on international trade. Those policies that have "no, or at most minimal trade-distorting effects or effects on production" are placed in the green box and are not subjected to any constraint. There is a second box (the blue box) specifically designed to direct payments which are accompanied by programs aimed at limiting production. Finally, there is a third box (the amber box) which includes all policies that are deemed to be trade distorting. These "amber" policies are subject to reductions which are applied on a Aggregate Measure of Support (AMS). The market price support system presented in our analytical framework is clearly an amber policy and its contribution to the AMS is given by the product of the domestic supply by the difference between the domestic price and the world price. On the other hand, the production quota system is not an amber policy but, by its impact on price and production, it has some induced impacts on the contribution of the market price support system to the AMS. Returning to figure 2, the initial AMS is given by the area $P 0 P W f d$. It reduces to the area $P W P h l$ in the price management scheme and to the area $P B P W c g$ in the quantity management scheme. ${ }^{6}$ So both management schemes lead to a reduction of the AMS but it is theoretically impossible to determine which reduction is highest. At this stage, it must be clear that both management schemes would not be WTO compatible if the AMS must be put to zero.

Finally, the negotiations on the market access chapter are really complex due to the multiplicity of rules and instruments. We just stress here that the enforcement of the quantity management scheme relies on a greater tariff (at least equal to the $c g$ distance on figure 2) than the price management scheme (at least equal to the $i g$ distance on figure 2) in order to prevent surge of imports. In other words, the maintenance of the community preference principle, and the producers ask for it, is fundamental in the quantity management scheme.

To sum up, the quantity management scheme is theoretically less sustainable at the WTO than the price management scheme, mainly on the market access dossier. In practice, does it really matter? This is clearly an empirical issue that depends on many factors, notably the evolution of world market conditions and world prices. Let's suppose for a while that the world price on figure 2 is equal to the equilibrium price $P$. In this case, the price management scheme is fully WTO compatible while the quantity management scheme still needs to be negotiated. In the same vein, the effective impacts on welfare of the two management schemes discussed in the previous paragraph depend to a large extent on the world market conditions. Thus we now turn to the empirical part of our paper.

\section{Price versus Quantity Management: An Empirical Analysis}

\section{Modelling Framework}

Our empirical comparison of the two management schemes is performed with a CGE model. The general structure of this CGE model is outlined in table 2. It is a static, single-country, multi-sector CGE model of the EU15 economy benchmarked to data for 1995. The model highlights the agricultural and food sectors and can

\footnotetext{
${ }^{6}$ It clearly appears within this discussion that the three areas of agricultural negotiations are not completely independent (see de Gorter (1999) for a comprehensive and useful discussion of this point).
} 
therefore be referred as a "sector-focused" model. The model is neo-classical, assuming perfect competition in all markets and without any risk factors. Accordingly, this model adopts simplifying assumptions and therefore can not provide a definitive answer to our purpose of comparing two agricultural policies. ${ }^{7}$ It nevertheless sheds a first light to this topic by considering simultaneously all agricultural sectors and moreover the whole food chain. We only stress below the most important characteristics of this model for the present analysis; more details are available from Gohin and Meyers (2002).

The first originality of the version of the model used for this paper comes from the disaggregation of the EU economy into activities and commodities (see table 3). The model identifies 17 sectors and 54 products. Many sectors have multi-product technologies and moreover, some commodities may be supplied by different sectors. Concerning agriculture, we consider one aggregate sector, 19 sub-sectors and 23 commodities. At the food processing level, the current version identifies 6 sectors and 21 commodities. Finally, the 10 sectors of the rest of the economy are mono-product. This rather detailed level of disaggregation of the food complex is motivated by three factors. Firstly, it allows us to capture the main forward and backward linkages among the various agricultural activities on the one hand, among these agricultural sectors and their economic environment (food processing, raw material suppliers) on the other hand. Secondly, it facilitates the specification of agricultural production technology, where substitution among intermediate inputs, as well as between intermediate inputs and primary factors of production, plays a crucial role. Thirdly, it enables accurate representation of the intricate workings of main CAP instruments.

This modelling of CAP instruments is the second originality of the model. In a general way, the main agricultural policy instruments are modelled explicitly and in a complementary fashion. Explicit modelling of policy instruments means that they are represented as closely as possible to their real working. Complementary modelling means that regime switches are allowed. Practically speaking, our CGE model provides a detailed treatment of the following CMOs: arable crops, dairy, sugar, beef meat, pig meat and eggs and poultry, and of the following policy measures: price support, supply control, trade and income support. Table 4 details the connection between CMOs and policy measures. At this stage, two remarks are in order. Firstly, the Agenda 2000 CAP reform introduces new policy instruments that are explicitly taken into account in our CGE model. Secondly, the WTO classification of these detailed measures is straightforward, allowing us to contemplate various simulations in line with the multilateral trade negotiations.

The third originality we want to underline is the specification of price elasticities in this model. It is wellrecognised (and quite obvious) that the specifications of production technologies and consumers' preferences (or, equivalently, price and income elasticities) are fundamental in all applied models, either of Partial Equilibrium (PE) or General Equilibrium nature. ${ }^{8}$ Despite this evidence, many CGE analysis (and even PE analysis) are still performed with poor representations of substitution possibilities at the demand and supply sides. This is not the case with our model which uses regular-flexible functional forms for the specification of production technologies and consumers preferences. As an example, we provide in table 5 the matrix of price

\footnotetext{
${ }^{7}$ Our CGE model is static, i.e. we do not specify dynamic behaviour of economic agents. That does not prevent the usual analysis of short run / long run impacts which mainly refers to the degree of mobility of primary factors of production between activities.

${ }^{8}$ For example, see Hertel (1985).
} 
elasticities of compensated final demand. These price elasticities are in line with available econometric results and are completely consistent with the properties of the demand theory.

\section{Experiment design}

The parameters as well as the exogenous variables (in particular, the levels of policy instruments, the world market prices) of our CGE model are calibrated using 1995 data. Accordingly, we first need to define a benchmark situation before comparing the two management schemes. At least three points must be considered for the definition of the benchmark. Firstly, the EU has adopted the Agenda 2000 CAP reform in 1999. Basically, this new CAP reform extends the previous MacSharry reform by lowering price support instruments and increasing direct payment instruments. Thus we introduce this reform in our benchmark but do not consider currents proposals on the MTR. Secondly, the mid nineties were characterised by high world prices of agricultural products, reduced gaps between European and world prices and limited European export subsidies. Using 1995 data as the benchmark is therefore likely to underestimate the impacts of export subsidies. Since the late nineties, world prices have considerably decreased and European export subsidies came back up, at least for cereals (see figure 1). Using recent data for our policy evaluation is likely to lead to stronger impacts of these export subsidies. But many agricultural projections (for instance, FAPRI, OECD, USDA) foresee favourable world market developments and high world prices for forthcoming years of this decade. So it is very difficult to define the correct world market conditions. Then we will perform a sensitivity analysis to the world market conditions. In the base case, we assume that world market conditions in the benchmark are similar to those that prevailed in 1995. Finally, we check that Uruguay Round Agreement on Agriculture (URAA) constraints, as defined in the domestic support and export competition commitments, are satisfied in this benchmark. All other parameters and exogenous variables specified in our CGE model are left unchanged. In particular, the growth of population, the technical change, evolution of consumer tastes, ... are not taken into account. By way of consequence, our reference situation does not intend to represent a precise year in the 2000s.

Endowed with our computed reference situation, we then consider the two management schemes of a phasing out of EU export subsidies. We focus the analysis on the following products: soft wheat, barley, maize, beef meat, pig meat, eggs, poultry meat, butter, skimmed milk powder, cheese, other dairy products, cereal processed products. The price management scenario is implemented by assuming that domestic prices of all these products can decrease and that supply control measures (land set-aside, dairy quotas, animal density limits) are left at their Agenda 2000 levels. The quantity management scenario differs from the price management scenario by assuming that dairy quotas are reduced. We test two percentage reductions of the dairy quota $(-6 \%$ and $-7.5 \%$ with respect to the Agenda 2000 level), as it is not obvious for policy makers to anticipate the level of domestic demand in the reference situation and the quantity that will leave the domestic price unchanged. In this last scenario, prices of all products are still free to adjust, upwards or downwards. As already mentioned in the theoretical analysis, the quantity management scheme strongly relies on the assumption that the community preference principle can be preserved. Thus we assume in this scenario that new flow of imports of any agricultural and food product cannot enter the EU market. In other words, we implicitly assume that the EU is able to prevent new imports with actual commitments on tariffs and/or new measures of protection.

We recognize that our comparative analysis is very illustrative as we only focus on the dairy sector and exclude sugar export subsidies (and quotas) from the analysis. But this offers the great advantage that analysis of results 
is simpler to present, compared to a "multiple shock" scenario, and (we hope so) more understandable. Moreover, we believe that this is not completely irrelevant, in particular because the reform of the sugar CMO has been several times postponed and that there are actually significant oppositions to an increase of dairy quotas in the context of the MTR debates.

\section{Results and discussion}

\section{Brief description of the reference situation}

Selected results of the reference scenario are reported in table 6 . We provide the reference values of export subsidies, the ratios between world and domestic prices and the shares of export in domestic production. ${ }^{9}$ The main interesting characteristics of this reference situation are the followings. Export subsidies on cereal products are nearly zero. In fact, it remains very few export subsidies on coarse grains ( 2 million euros on barley). We also note that the domestic price of barley is slightly higher than the world price and that exports of barley represent a small share of domestic production. Accordingly, the removal of export subsidies on this cereal is likely to lead to very limited reductions of domestic price and/or domestic production. Export subsidies on bovine meat are also zero in the reference situation. In contrast to the cereals case, this comes from the fact that exports are zero. The domestic price of bovine meat is far greater than the world price and the preservation of significant market access instruments is clearly critical for the equilibrium of this domestic market. This $100 \%$ reduction of bovine meat export subsidies mainly comes from the intervention price reduction decided in the Agenda 2000 CAP reform and which stimulates domestic consumption. ${ }^{10}$ On the other hand, domestic consumption of other meats is penalized by this measure and, by way of consequences, there remain some export subsidies on poultry meat and pig meat in this reference situation. One may note that, as a whole, export subsidies on all meats are significantly reduced compared to the mid 1990s. The differences between domestic and world prices of the other meats are sizeable, as well as their export shares in total domestic productions. Finally, export subsidies on dairy products are still considerable in the reference situation. They amount to 1.8 billion euros, which represents a $20 \%$ reduction compared to 1995 . The dairy quota increase, decided in the Agenda 2000 CAP reform, partly compensates the intervention price reduction effect on dairy export supplies. Furthermore, one can note that the differences between prices are still substantial, notably for butter and the aggregate of other dairy products (which includes whole milk powder), and that export shares are also significant. In particular, exports of skimmed milk powder represent $24 \%$ of domestic production. The phasing out of export subsidies will thus have huge impacts on the dairy sectors. In a general way, these reference figures are in line with previous analysis (see introduction).

\footnotetext{
${ }^{9}$ We adopt in our CGE model the traditional Armington specification to model import demand functions and export supply functions. Accordingly, there is no unique price for the domestically produced good but a price which differs according to the destination. The ratios reported in table 6 are computed using the domestic price of exported products.

${ }^{10}$ We once again underline that our reference situation is built on simplifying assumptions, notably that the tastes of consumers on all food products are unchanged with respect to the base situation (1995).
} 


\section{Impacts of the price management scenario}

Market impacts of our policy scenarios are reported in table 7 and welfare impacts are displayed in table 8 . We first discuss the results of the price management scheme before turning to those obtained with the quantity management schemes. As expected, the phasing out of export subsidies has limited impacts on the arable crop markets. For instance, domestic supply of soft wheat decreases by only $0.4 \%$ relative to the benchmark; its domestic consumption also decreases by $0.6 \%$, exports slightly increases $(+1.5 \%)$ and finally domestic price marginally decreases $(0.1 \%)$. Effects on coarse grains (notably barley) are a little more marked, as they benefit from some export subsidies in the reference situation. In a general way, the observed effects in the arable crop markets mainly come from the domestic demand side. Domestic demands of cereals decrease due to a contraction of animal production and the cereal price reduction does not compensate this first effect. Surprisingly, the reduction of cereals production does not translate into an increase of oilseed production. For instance, rapeseed production decreases by $1.8 \%$. Here too the demand side explains most of the results. Domestic demand of meals also decreases due to an contraction effect in this derived demand while domestic demand of oils decreases due to a substitution effect between fat products (including butter). As far as the white meat markets are concerned, results are as expected. Domestic productions decrease and domestic demands increase, so that export supplies contract. Despite zero export subsidies in the reference situation, the impacts on the bovine meat market are significant. Domestic production even declines as much as poultry meat production. Again, this mainly comes from a demand effect. Domestic demand of bovine meat declines as a result of the substitution between all meats. Since this market is just "domestically balanced" in the reference situation, the reduction of domestic demand directly translates into a reduction in domestic production. The meat price effects may at first sight appear surprising, in particular the increase of the bovine meat price. However, one must note that the evolution of meat prices ratio is fully consistent with the evolution of their domestic consumptions. As expected, the main impacts of the phasing out of export subsidies are observed on the dairy markets. EU dairy products can hardly compete on the world markets without export subsidies, due to the huge differences between prices in the reference situation. Accordingly, exports significantly decline. The most severe reduction is for butter which experiences a $92.6 \%$ reduction in exports. Domestic prices of dairy products significantly decrease but with a rather limited effect on the domestic demand. For instance, domestic demand of butter "only" increases by $4.2 \%$ when its price decreases by $19.3 \%$. But butter exports represent $9.2 \%$ of domestic production in the reference situation. Thus domestic production decreases (by $4.6 \%$ ) to restore market equilibrium. Price reductions of dairy products are translated into a huge decrease of milk price. The latter is so high that the domestic production of raw milk is lower than the milk quota level. In other words, milk production quotas are no longer binding at the EU level. ${ }^{11}$ The domestic production of raw milk decreases by $3.8 \%$ with respect to the reference situation, which explains part of the reduction of bovine meat production. The main losers of this policy scenario are obviously the milk farmers. The first column of table 8 indicates that their value added decreases by nearly 3.89 billions euros or by $23.5 \%$ with respect to the reference situation. This column also reveals that the arable crop growers and non-ruminant farmers also lose with this scenario but in much smaller proportions (respectively, 239 and 68 millions euros). As a whole, the agricultural sector experiences a welfare

\footnotetext{
${ }^{11}$ Let's recall that we do not increase or introduce new direct payments in our policy scenarios.
} 
loss of 3.93 billions euros, which represents $5.9 \%$ of their value added in the reference situation. The food processing sectors are also adversely affected by this scenario. As a whole, they lose 1.2 billion euros of value added (2.8\% of their reference value added). The milk processing industry is the main contributor to this welfare effect, mainly due to a contraction of production. Basically, with less raw milk available for processing, this sector creates less value added. The main winner of this policy scenario is obviously the domestic consumer and as a whole the EU welfare increases by 2.652 billions euros. ${ }^{12}$

\section{Impacts of the quantity management scenarios}

These figures may help to understand the fear of farmers (especially milk farmers) about the phasing out of export subsidies. Let's consider the quantity management scenario where it is assumed that policy makers decide to reduce the milk quota level by $6 \%$ with respect to the Agenda 2000 level (or by $3.8 \%$ with respect to the base year 1995). We first compare the market impacts of this scenario to those just described (see table 7). The milk production decreases by $6 \%$ with respect to the reference run or by $2.2 \%$ with respect to the level obtained with the price management scheme. This further reduction of domestic supply allows to keep milk and dairy product prices very close to their reference levels. The milk price decrease is limited to $1.8 \%$, compared to the $17.3 \%$ obtained in the price management scheme. Compared to the price management results, the reduced supply is mainly supported by a reduction of domestic demands and to a lesser extent by exports. For instance, domestic demand of butter only increases by $0.5 \%$, compared to $4.2 \%$ in the price management scenario. The impacts of this scenario on the other sectors are qualitatively similar to the impacts of the price management scenario. In particular, domestic production of cereals still decreases, by a slightly larger extent because the derived demand for animal feeding suffers from a greater contraction effect. On oilseed markets, we have two competing effects. On the one hand, the derived demand of meals decreases a little more according to the same contraction effect. On the other hand, the final demand of oils decreases less than in the price management scenario, as there is less competition from butter. Because the value of the rapeseed mainly depends on its oil and to a lesser extent on its meal, the "oil" effect dominates the "meal" effect so that domestic production of rape decreases less $(0.5 \%$ compared to $1.8 \%$ ). Finally, the main induced effects on meat markets is a greater reduction of bovine meat production and a greater increase of its price. The welfare effects of this scenario are reported in the second column of table 8 . It clearly appears that these welfare effects are very different. Milk farmers now gain by 394 millions euros and the value added of the whole agricultural sector increases by 522 millions euros. But this comes at the expense of both processing industries and domestic consumers. The value added of the food processing industries decrease by 1603 millions euros. Nevertheless, the EU economy still gains by eliminating export subsidies, by 2333 millions euros. Comparing the welfare effects of the first two scenarios, we find that the welfare gain of farmers is equal to 4457 millions euros and the EU welfare loss is equal to 319 millions euros. We thus find that the milk quota instrument is rather efficient in transferring support to agricultural producers, and this is in line with many previous analysis relying on static and perfect competition modelling assumptions.

It may be tempting to conclude here that a production quota (and more generally supply management measures) is an advantageous policy instrument to support farm incomes. As already mentioned, our modelling framework

\footnotetext{
${ }^{12}$ This welfare measure takes into account the loss of agricultural and food processing sectors and roughly corresponds to the area $\mathrm{cgfeh}$ on figure 2 .
} 
is not sufficiently broad in scope to provide a definitive answer to this question. However, it allows to show that a policy relying strongly on this instrument may be difficult to define. In that respect, the third scenario is helpful. This scenario considers a quantity management scheme where the milk quota level is reduced by $7.5 \%$ with respect to the Agenda 2000 level. In a general way, the market effects are qualitatively similar to those identified in the second scenario. The welfare effects are also in the same directions but their magnitude are dramatically changed. With the sole $1.5 \%$ change in the milk quota level, the agricultural value added increases by nearly 3.5 billions euros ( $5.3 \%$ of the reference value added) compared to 0.5 billion euros in the second scenario. This huge difference simply reflects the inelasticity of food demand at the aggregate level. As we prevent new imports in this scenario, the reduction of domestic supply necessarily conducts to a huge increase of domestic price. Thus we believe that the definition of the "good" level of supply control measures is not a trivial matter.

\section{Sensitivity analysis}

The preceding results obviously depend on many assumptions and we examine in this paragraph the sensitivity of welfare effects to the world market conditions. ${ }^{13}$ Table 9 reports the results of this sensitivity analysis. We test two alternative hypotheses. The first one assumes that world market conditions are better for all agricultural and food products. Practically, we consider that the inverse export demand functions for all these products are $10 \%$ higher than previously assumed. The second alternative is symmetric ( $-10 \%$ with respect to the base). At this stage, two remarks are in order. Firstly, world prices are assumed, in our CGE model, to be dependent of EU exports and imports and thus are endogenous. On the other hand, the impacts of other countries on these world prices are not explicitly specified and the $10 \%$ assumption indicates a change of net trade position of these other countries. Secondly, these alternative assumptions about world market conditions also affect the results of the reference scenario. We then compare two management scenarios (price and quantity with $6 \%$ reduction of milk quota level) on different benchmark situations.

Let's concentrate on the case of better world market conditions and compare it to the base. First of all, we observe that the price management scenario leads to smaller EU welfare gains: 2048 millions euros compared to 2652. This simply reflects the fact that the difference between domestic and world prices is smaller than in the base and accordingly there are less export subsidies in the new reference situation. But the difference between the two management schemes is roughly independent of these world market conditions: 319 millions euros in the base, 353 millions under the favourable conditions. The most interesting result concerns the evolution of the agricultural value added. The price management of the phasing out of agricultural export subsidies has roughly the same effect on this variable under the two world market conditions (reduction of 4071 and 3935 millions euros). This can be explained as follows. On the one hand, arable crop farming as well as non-ruminant farming gain more because they are able to export more on the world market. On the other hand, animal feeds are more expensive and the price increase of bovine meat is more limited, so that ruminant farming and milk farming loose more. The sum of these two main effects is slightly negative.

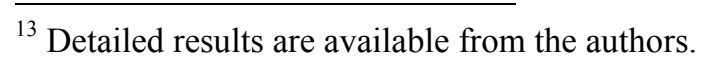


To the contrary, the world price assumptions significantly affect the impact of the quantity management scenario on the agricultural value added: +522 in the base, +2406 in the favourable conditions. This results from the fact that the EU relies less on subsidised exports, notably of skimmed milk powder, and consequently that the domestic supply reduction generates more price increase in the domestic market. This strengthens our previous finding concerning the extreme difficulty to determine "good" levels for supply control measures.

\section{Concluding comments}

The present round of multilateral trade negotiations at the WTO is likely to put an end to European direct export subsidies on agricultural and food products. Available economic analyses as well as negotiations positions of WTO members seem to converge on this outcome. This paper attempts to evaluate such a policy scenario in isolation from other negotiations chapters (domestic support and market access), even if there are obviously some linkages. The main contribution of this paper is to compare two management schemes of this shock on the EU economy. The first one (labelled the price management scheme) has confidence in the equilibrium role of market prices while the second one (labelled the quantity management scheme) favours a supply management approach. After a theoretical analysis of advantages and drawbacks of both schemes, we conduct an empirical analysis using a CGE model focused on EU agricultural and food sectors. The main originalities of this applied model, which constitute significant departures from other CGE models currently in use, are threefold: a fine disaggregation of agricultural and food products and sectors, a fine representation of CAP instruments and a flexible regular specification of production technologies and consumer preferences. Moreover, this modelling framework allows to identify winners and losers in addition to evaluate market impacts of policy scenarios.

Both management schemes are evaluated against a common benchmark situation which assumes full implementation of the Agenda 2000 CAP reform. In this reference situation, export subsidies on cereals and meat products are low while still considerable on dairy products. In accordance with expectations, our empirical results show that the phasing out of agricultural export subsidies will have huge effects on the dairy sector and more limited impacts on arable crops and meat sectors, whatever is the management scheme. Our empirical analysis also reveals that the choice of a management scheme has a substantial bearing on sectoral welfare effects. Agricultural value added greatly reduces with the price management scheme and quite independently of assumptions regarding world market conditions. At the reverse, this value added not necessarily decreases with the quantity management scheme. We even find that it can increase in case of strong supply management and/or favourable world market conditions. But this is to the detriment of the "downstream agents" of the food chain (food processing and consumers). As a whole, total welfare effects for the EU economy are rather similar across management schemes, but still slightly more favourable in the price management scheme.

Accordingly, our analysis once again illustrates the relative efficiency of an agricultural policy relying on effective supply management measures. Above all, its main contribution is to demonstrate that the precise definition of such a policy, in particular the levels of supply control measures, is exceptionally tricky. Supporters of an evolution of the CAP towards this direction must be aware of these consequences. 


\section{References}

Alston, J.M., James, J. (2003). The Incidence of Agricultural Policy. In Bruce Gardner and Gordon Rausser, eds., Handbook of Agricultural Economics, Vol 2B. New York, North Holland.

Bienfield, J. Donnellan, T., Hanrahan, K., McQuinn, K., Westhoff, P. (2001). The Impact of WTO Export Subsidy Reductions on Agricultural Output, Prices and Farm Incomes in Ireland. Available from Teagasc webpage.

Bullock, D.S., Salhofer, K. (2003). Judging agricultural policies: a survey. Agricultural Economics, 28, $225-243$. de Gorter, H., Meilke, K.D. (1989). Efficiency of alternative policies for the EC's common agricultural policy. American Journal of Agricultural Economics, 71, 592-603.

de Gorter, H. (1999). Market Access, Export Subsidies and Domestic Support Measures: Issues and Suggestions for New Rules. Paper prepared for the World Bank Conference on "Agriculture and the New Trade Agenda from a Development Perspective: Interest and Options in the Next WTO Negotiations", Geneva.

Dimaranan, B., Hertel, T., Keeney, R. (2003). OECD Domestic Support and the Developing Countries. Paper presented at the sixth annual conference on Global Economic Analysis, The Hague, The Netherlands.

Elbehri, A., Leetmaa, S. (2001). How significant are export subsidies to agricultural trade? Trade and welfare implications of global reforms. Paper presented at the annual conference of the American Agricultural Economics Association, Chicago, Illinois.

FAPRI (2002). The Doha Round of the World Trade Organisations: Appraising Further Liberalisations of Agricultural Markets. FAPRI Working Paper 02-317.

Francois, J., van Meijl, H., von Tongeren, F. (2003). A forward-looking analysis of the Doha Round. Paper presented at the sixth annual conference on Global Economic Analysis, The Hague, The Netherlands.

Gardner, B. (1983). Efficient redistribution through commodity markets. American Journal of Agricultural Economics, 65, 225-234.

Gohin, A., Gorin, O., Guyomard, H., Le Mouël, C. (1999). Interprétation économique, avantages et limites du principe de découplage des instruments de soutien des revenues agricoles. Notes et Etudes Economiques, 10, 1037.

Gohin, A., Meyers, C. (2002). The phasing out of export subsidies: Impacts on EU agriculture. Paper presented at the second International Conference on Policy Modelling, Brussels.

Guyomard, H., LeBris, K. (2003). The Fischler's Proposals for the Common Agricultural Policy : Paving the Way for the Future ? INRA-ESR Working paper 03-05, Rennes.

Hertel, T. (1985). Partial vs. General Equilibrium Analysis and Choice of Functional Form: Implications for Policy Modeling. Journal of Policy Modeling, 7, 281-303

Leetmaa, S. (2001) Analysis of Export Subsidy Elimination. In "Agricultural Policy Reform in the WTO - The Road Ahead" edited by Burfisher, M. USDA, Agricultural Economic Report No 802.

OECD (2000). A Forward-Looking Analysis of Export Subsidies in Agriculture. Paris. 
Van Meijl, H., Von Tongeren, F. (2002). The Agenda 2000 CAP reform, world prices and URAA GATT-WTO export constraints. Paper presented at the third Annual Conference on Global Economic Analysis, Melbourne, June 27-30.

Vanzetti, D., Peters, R. (2003). Strategic interactions in trade policy negotiations. Paper presented at the sixth annual conference on Global Economic Analysis, The Hague, The Netherlands. 
Figure 1. Evolution of EU export subsidies on main agricultural and food products

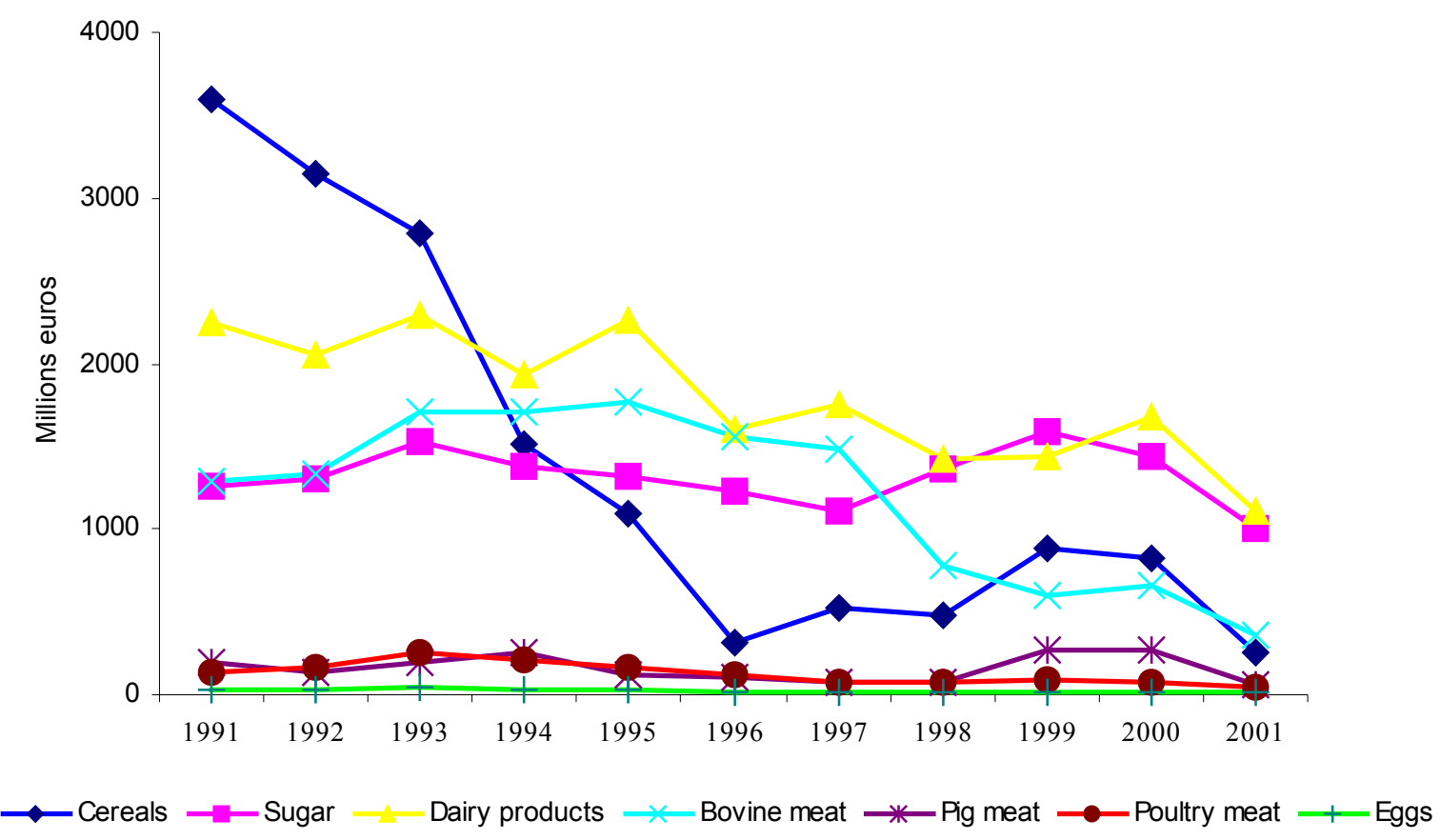

Source : FEOGA. 
Figure 2. Market impacts of two management schemes of the phasing out of export subsidies

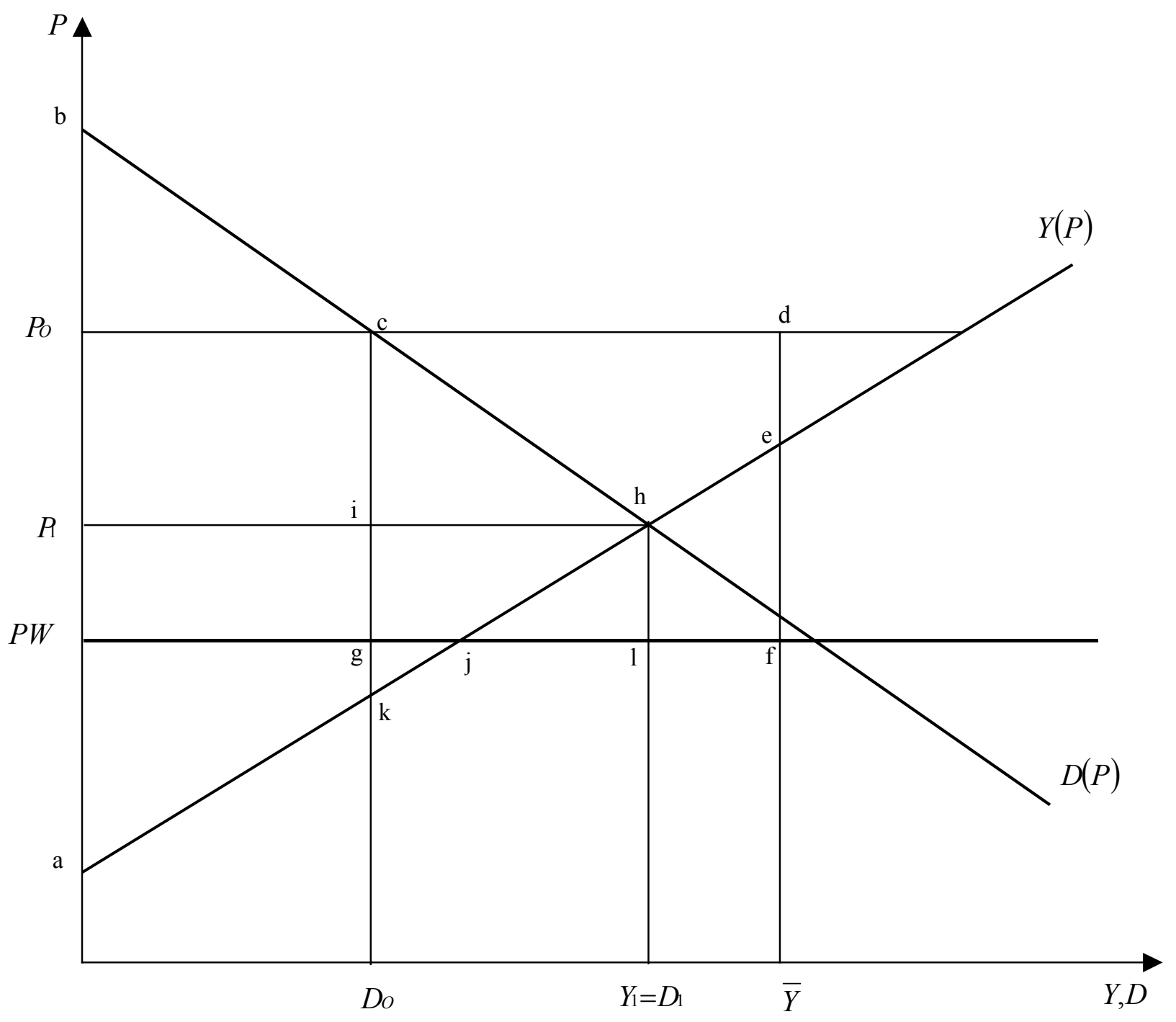

Welfare impacts of two management schemes of the phasing out of export subsidies

\begin{tabular}{|c|c|c|c|c|c|c|}
\hline & $\begin{array}{l}\text { Initial } \\
\text { situation } \\
(\mathrm{I})\end{array}$ & $\begin{array}{c}\text { Price } \\
\text { management } \\
\text { (II) }\end{array}$ & $\begin{array}{l}\text { Difference } \\
(\mathrm{II})-(\mathrm{I})\end{array}$ & $\begin{array}{c}\text { Quantity } \\
\text { management } \\
\text { (III) }\end{array}$ & $\begin{array}{l}\text { Difference } \\
(\mathrm{III})-(\mathrm{I})\end{array}$ & $\begin{array}{l}\text { Difference } \\
(\mathrm{III})-(\mathrm{II})\end{array}$ \\
\hline Producers profit & aPo de & $a P h$ & - Po P hed & aPo ck & -cdek & Po $P$ ci-ihk \\
\hline Consumer surplus & $P o b c$ & $b P h$ & $+P_{o} P h c$ & $P o b c$ & 0 & - Po $P$ hc \\
\hline Public expenditure & $c d f g$ & 0 & $-c d f g$ & 0 & $-c d f g$ & 0 \\
\hline $\begin{array}{l}\text { Total domestic } \\
\text { welfare }\end{array}$ & abcgj-jef & $a b h$ & $+c g f e h$ & $a b c k$ & ejf-gjk & -chk \\
\hline
\end{tabular}


Table 1. Literature review on the impacts of the phasing out of agricultural export subsidies (Differences in percentages from the benchmark)

\begin{tabular}{|c|c|c|c|c|c|}
\hline Study & OECD* & $\begin{array}{c}\text { Elbehri and } \\
\text { Leetma }\end{array}$ & Leetma** & Bienfield et al. & $\begin{array}{l}\text { Gohin and } \\
\text { Meyers*** }\end{array}$ \\
\hline $\begin{array}{l}\text { Wheat } \\
\text { European price } \\
\text { World price } \\
\text { European exports }\end{array}$ & $\begin{array}{c}-3 \\
-1 \\
+14\end{array}$ & $\begin{array}{l}-0.4 \\
+0.3 \\
+0.6\end{array}$ & $\begin{array}{c}-8.6 \\
-6.1 \\
+19.5\end{array}$ & $\begin{array}{c}-7 \\
\text { NA } \\
+3\end{array}$ & $\begin{array}{c}0 \\
\text { NA } \\
+0.4\end{array}$ \\
\hline $\begin{array}{l}\text { Coarse grains } \\
\text { European price } \\
\text { World price } \\
\text { European exports }\end{array}$ & $\begin{array}{l}-14 \\
+1 \\
-59\end{array}$ & $\begin{array}{l}-0.7 \\
+1.4 \\
-14.4\end{array}$ & $\begin{array}{l}-13.2 \\
+4.9 \\
-17.3\end{array}$ & $\begin{array}{l}-9,3 \\
\text { NA } \\
\text { NA }\end{array}$ & $\begin{array}{l}-2.3 \\
\text { NA } \\
-71.6\end{array}$ \\
\hline $\begin{array}{l}\text { Beef } \\
\text { European price } \\
\text { World price } \\
\text { European exports } \\
\end{array}$ & $\begin{array}{l}-14 \\
\sim 0 \\
-72 \\
\end{array}$ & $\begin{array}{l}-0.3 \\
+1.5 \\
-6.9 \\
\end{array}$ & $\begin{array}{l}-59.7 \\
\text { NA } \\
-100 \\
\end{array}$ & $\begin{array}{l}-17 \\
+3 \\
-70 \\
\end{array}$ & $\begin{array}{l}+1.6 \\
\text { NA } \\
-14.2 \\
\end{array}$ \\
\hline $\begin{array}{l}\text { Pork/Poultry } \\
\text { European price } \\
\text { World price } \\
\text { European exports }\end{array}$ & $\begin{array}{c}+2 \\
0 \\
-32\end{array}$ & $\begin{array}{l}-0.2 \\
+0.9 \\
-2.4\end{array}$ & $\begin{array}{c}-13.2 \\
+10.1 \\
-44\end{array}$ & $\begin{array}{l}\text { NA } \\
\text { NA } \\
\text { NA }\end{array}$ & $\begin{array}{l}-0.4 \\
\text { NA } \\
-35.4\end{array}$ \\
\hline $\begin{array}{l}\text { Milk } \\
\text { European price } \\
\end{array}$ & -10 & -0.2 & NA & -17 & -18.7 \\
\hline
\end{tabular}

*: Results obtained in the base case regarding the value of the Euro

**: Results obtained with a Euro stronger than dollar

***: Results obtained with the flexible specification 
Table 2. General characteristics of the CGE model

1. Single-country, multi-sector, static CGE model applied to EU15, benchmarked to data for 1995, focused on agricultural and food processing sectors

2. 17 multi-product activity sectors and 54 commodities: 1 aggregate agricultural sector and 23 agricultural commodities, 6 food processing industries and 21 food products, 10 mono-product sectors in the rest of the economy

3. 3 primary factors of production (labor, capital, land), one representative household, one foreign zone

4. Profit maximization of producers subject to constant returns to scale production technologies; utility maximization of the representative household subject to budget constraints

5. Regular-flexible representation of production technologies and preferences

6. Imperfect substitution between domestic and foreign commodities on both the import and export sides; large country assumption on both the import and export side

7. Explicit and complementary modelling of main policy instruments (price support, supply control, trade instruments and income support) of the following Common Market Organisations (arable crops, dairy, sugar, beef meat, pig meat, eggs and poultry)

8. Imperfect mobility of labor and capital across activity sectors ; perfect mobility of land

9. Competitive markets and neo-classical macro-economic closure 
Table 3. Sectors and commodities correspondence

\begin{tabular}{|c|c|c|}
\hline \multicolumn{2}{|l|}{ Sectors } & Commodities \\
\hline \multicolumn{3}{|r|}{ AGRICULTURE } \\
\hline $\begin{array}{l}\text { Sector } \\
\text { Agriculture }\end{array}$ & $\begin{array}{l}\text { Agricultural sub-sectors } \\
\text { Soft wheat } \\
\text { Barley } \\
\text { Maize } \\
\text { Rape } \\
\text { Sunflower } \\
\text { Soya } \\
\text { Protein crops } \\
\text { Sugar beet } \\
\text { Fodder } \\
\text { Poultry } \\
\text { Pigs } \\
\text { Laying hen } \\
\text { Dairy cows } \\
\text { Suckling cows } \\
\text { Beef calf } \\
\text { Calf rearing } \\
\text { Heifers } \\
\text { Bulls and Steers } \\
\text { Other agricultural activities }\end{array}$ & $\begin{array}{l}\text { Soft wheat } \\
\text { Barley } \\
\text { Maize } \\
\text { Rape } \\
\text { Sunflower } \\
\text { Soybean } \\
\text { Protein crops } \\
\text { A\&B Sugar beet, C sugar beet } \\
\text { Fodder } \\
\text { Poultry, Organic nitrogen, Organic phosphate, Organic } \\
\text { potassium } \\
\text { Pigs, Organic nitrogen, Organic phosphate, Organic potassium } \\
\text { Eggs, Poultry, Organic nitrogen, Organic phosphate, Organic } \\
\text { potassium } \\
\text { Bovine cattle, Raw milk, Calves, Dairy cows, Organic nitrogen, } \\
\text { Organic phosphate, Organic potassium } \\
\text { Bovine cattle, Calves, Suckling cows, Organic nitrogen, } \\
\text { Organic phosphate, Organic potassium } \\
\text { Bovine cattle, Organic nitrogen, Organic phosphate, Organic } \\
\text { potassium } \\
\text { Bovine cattle, Heifers, Bulls and Steers, Dairy cows, Organic } \\
\text { nitrogen, Organic phosphate, Organic potassium } \\
\text { Bovine cattle, Dairy cows, Suckling cows, Organic nitrogen, } \\
\text { Organic phosphate, Organic potassium } \\
\text { Bovine cattle, Organic nitrogen, Organic phosphate, Organic } \\
\text { potassium } \\
\text { Other agricultural products }\end{array}$ \\
\hline \multicolumn{3}{|r|}{ FOOD PROCESSING } \\
\hline Meat indus & & Bovine meat, Pig meat, Poultry meat, Carcass meals \\
\hline Dairy indus & & Butter, Skimmed milk powder, Cheese, Other dairy products \\
\hline Compound & ndustry & Compound feed \\
\hline Cereal proc & industry & Grains bran, Corn gluten feed, Other cereal processed products \\
\hline Oilseed cru & industry & $\begin{array}{l}\text { Rape oil, Sunflower oil, Soybean oil, Rape cake, Sunflower } \\
\text { cake, Soybean cake }\end{array}$ \\
\hline Sugar indus & & A\&B Sugar, C sugar, Sugar beet pulp, Molasses \\
\hline \multicolumn{3}{|c|}{ REST OF THE ECONOMY } \\
\hline Mineral nit & & Mineral nitrogen \\
\hline Mineral ph & & Mineral phosphate \\
\hline Mineral pot & & Mineral potassium \\
\hline Pesticides & & Pesticides \\
\hline Veterinary & & Veterinary products \\
\hline Fish meals & & Fish meals \\
\hline Other energ & feed & Other energy rich feed \\
\hline Other prote & feed & Other protein rich feed \\
\hline Other feed & ients & Other feed ingredients \\
\hline Other secto & & Other sectors \\
\hline
\end{tabular}


Table 4. Policy measures by Common Market Organisation in the GOAL model

\begin{tabular}{|c|c|c|c|c|}
\hline & Price support & Supply controls & Trade instruments & Income support \\
\hline Arable crops & Intervention price for cereals & Land set aside & $\begin{array}{l}\text { Export subsidies for cereals } \\
\text { Tariff rate quotas for cereals }\end{array}$ & Land direct payments \\
\hline Dairy & $\begin{array}{l}\text { Intervention price for butter and } \\
\text { skimmed milk powder } \\
\text { Inputs subsidies for butter and } \\
\text { skimmed milk powder }\end{array}$ & Production quota on milk & $\begin{array}{l}\text { Export subsidies for dairy } \\
\text { products } \\
\text { Tariff rate quotas for dairy } \\
\text { products }\end{array}$ & Dairy cow direct payments* \\
\hline Sugar & $\begin{array}{l}\text { Intervention price for sugar } \\
\text { subject to production quota }\end{array}$ & $\begin{array}{l}\text { Production quotas on A\&B sugar } \\
\text { beet }\end{array}$ & $\begin{array}{l}\text { Export subsidies for sugar } \\
\text { subject to production quotas } \\
\text { Tariff rate quotas for sugar }\end{array}$ & \\
\hline Eggs and poultry & & & $\begin{array}{l}\text { Export subsidies } \\
\text { Tariff rate quotas }\end{array}$ & \\
\hline Pig meat & & & $\begin{array}{l}\text { Export subsidies } \\
\text { Tariff rate quotas }\end{array}$ & \\
\hline Beef meat & Intervention price for beef meat & Livestock stocking thresholds & $\begin{array}{l}\text { Export subsidies } \\
\text { Tariff rate quotas }\end{array}$ & $\begin{array}{l}\text { Suckling cow payments } \\
\text { Bovine male payments } \\
\text { Slaughter payments* }\end{array}$ \\
\hline
\end{tabular}

*: policy measure introduced with the Agenda 2000 CAP reform 
Table 5: Compensated price elasticities at the final demand level

\begin{tabular}{|c|c|c|c|c|c|c|c|c|c|c|c|c|c|c|c|}
\hline & $\begin{array}{c}\text { Bovine } \\
\text { meat }\end{array}$ & Pig meat & $\begin{array}{c}\text { Poultry } \\
\text { meat }\end{array}$ & Eggs & $\begin{array}{l}\text { Skim } \\
\text { powder }\end{array}$ & Cheese & $\begin{array}{l}\text { Other } \\
\text { Dairy }\end{array}$ & $\begin{array}{c}\text { Other } \\
\text { Agriculture }\end{array}$ & $\begin{array}{c}\text { Other } \\
\text { Cereal } \\
\text { processed }\end{array}$ & Butter & Rape oil & $\begin{array}{c}\text { Sunflower } \\
\text { oil }\end{array}$ & $\begin{array}{l}\text { Soyabean } \\
\text { oil }\end{array}$ & Sugar & $\begin{array}{c}\text { Other } \\
\text { products }\end{array}$ \\
\hline Bovine meat & -0.780 & 0.547 & 0.109 & -0.001 & 0.000 & -0.005 & -0.010 & -0.026 & -0.005 & -0.008 & -0.001 & -0.001 & -0.001 & -0.001 & 0.185 \\
\hline Pig meat & 0.366 & -0.731 & 0.241 & -0.001 & 0.000 & -0.005 & -0.010 & -0.026 & -0.005 & -0.008 & -0.001 & -0.001 & -0.001 & -0.001 & 0.185 \\
\hline Poultry meat & 0.187 & 0.620 & -0.932 & -0.001 & 0.000 & -0.005 & -0.010 & -0.026 & -0.005 & -0.008 & -0.001 & -0.001 & -0.001 & -0.001 & 0.185 \\
\hline Eggs & -0.006 & -0.009 & -0.003 & -0.606 & -0.026 & 0.574 & -0.093 & -0.026 & 0.006 & 0.007 & 0.001 & 0.001 & 0.001 & -0.006 & 0.185 \\
\hline Skim milk powder & -0.006 & -0.009 & -0.003 & -0.130 & -0.498 & -0.047 & 0.523 & -0.026 & 0.006 & 0.007 & 0.001 & 0.001 & 0.001 & -0.006 & 0.185 \\
\hline Cheese & -0.006 & -0.009 & -0.003 & 0.112 & -0.002 & -1.401 & 1.140 & -0.026 & 0.006 & 0.007 & 0.001 & 0.001 & 0.001 & -0.006 & 0.185 \\
\hline Other Dairy products & -0.006 & -0.009 & -0.003 & -0.009 & 0.010 & 0.574 & -0.727 & -0.026 & 0.006 & 0.007 & 0.001 & 0.001 & 0.001 & -0.006 & 0.185 \\
\hline Other Agriculture & -0.009 & -0.013 & -0.005 & -0.001 & 0.000 & -0.007 & -0.014 & -0.196 & 0.056 & -0.004 & -0.001 & -0.001 & -0.001 & 0.010 & 0.185 \\
\hline Other Cereal processed & -0.009 & -0.013 & -0.005 & 0.002 & 0.000 & 0.010 & 0.019 & 0.327 & -0.503 & -0.008 & -0.001 & -0.001 & -0.001 & -0.001 & 0.185 \\
\hline Butter & -0.038 & -0.057 & -0.022 & 0.005 & 0.001 & 0.026 & 0.053 & -0.057 & -0.020 & -0.207 & 0.047 & 0.049 & 0.047 & -0.012 & 0.185 \\
\hline Rape oil & -0.038 & -0.057 & -0.022 & 0.005 & 0.001 & 0.026 & 0.053 & -0.057 & -0.020 & 0.293 & -0.563 & 0.106 & 0.101 & -0.012 & 0.185 \\
\hline Sunflower oil & -0.038 & -0.057 & -0.022 & 0.005 & 0.001 & 0.026 & 0.053 & -0.057 & -0.020 & 0.293 & 0.102 & -0.559 & 0.101 & -0.012 & 0.185 \\
\hline Soyabean oil & -0.038 & -0.057 & -0.022 & 0.005 & 0.001 & 0.026 & 0.053 & -0.057 & -0.020 & 0.293 & 0.102 & 0.106 & -0.564 & -0.012 & 0.185 \\
\hline Sugar & -0.004 & -0.005 & -0.002 & -0.003 & -0.001 & -0.016 & -0.031 & 0.097 & -0.002 & -0.008 & -0.001 & -0.001 & -0.001 & -0.207 & 0.185 \\
\hline Other products & 0.001 & 0.002 & 0.001 & 0.000 & 0.000 & 0.001 & 0.002 & 0.005 & 0.001 & 0.000 & 0.000 & 0.000 & 0.000 & 0.000 & -0.015 \\
\hline Initial share & 0.73 & 1.10 & 0.43 & 0.12 & 0.02 & 0.62 & 1.23 & 2.26 & 0.39 & 0.16 & 0.03 & 0.03 & 0.03 & 0.23 & 92.64 \\
\hline
\end{tabular}


Table 6. Export subsidies, price wedges and share of exports in the reference situation

\begin{tabular}{|c|c|c|c|}
\hline & $\begin{array}{c}\text { Export subsidy } \\
\left(P_{O}-P W\right)\left(\bar{Y}-D_{o}\right) \\
\text { Millions euros }\end{array}$ & $\begin{array}{c}\text { World price/Producer price* } \\
\qquad P W / P_{O} \\
\%\end{array}$ & $\begin{array}{c}\text { Export/Production } \\
\qquad\left(\bar{Y}-D_{o}\right) / \bar{Y} \\
\%\end{array}$ \\
\hline Soft wheat & 0 & 100 & 9.7 \\
\hline Barley & 2 & 96.9 & 1.6 \\
\hline Processed cereals & 0 & 100 & 0.6 \\
\hline Bovine meat & 0 & 47.8 & 0 \\
\hline Poultry meat & 177 & 81.0 & 5.9 \\
\hline Pig meat & 125 & 91.1 & 3.5 \\
\hline Eggs & 29 & 82.0 & 3.4 \\
\hline Butter & 192 & 62.2 & 9.2 \\
\hline Skimmed milk powder & 66 & 88.9 & 24.0 \\
\hline Cheese & 566 & 74.3 & 9.1 \\
\hline Other dairy products & 992 & 69.7 & 7.1 \\
\hline
\end{tabular}

*: World price divided by the domestic price of exports. 
Table 7. Market impacts of two management schemes of the phasing out of agricultural export subsidies (Percentage differences from the reference situation)

\begin{tabular}{|c|c|c|c|c|c|c|c|c|c|c|c|c|}
\hline \multirow[b]{2}{*}{ Management } & \multicolumn{3}{|c|}{ Domestic production } & \multicolumn{3}{|c|}{ Domestic consumption } & \multicolumn{3}{|c|}{ Exports } & \multicolumn{3}{|c|}{ Domestic prices* } \\
\hline & Price & $\begin{array}{c}\text { Quantity } \\
6\end{array}$ & $\begin{array}{c}\text { Quantity } \\
7.5\end{array}$ & Price & $\begin{array}{c}\text { Quantity } \\
6\end{array}$ & $\begin{array}{c}\text { Quantity } \\
7.5\end{array}$ & Price & $\begin{array}{c}\text { Quantity } \\
6\end{array}$ & $\begin{array}{c}\text { Quantity } \\
7.5\end{array}$ & Price & $\begin{array}{c}\text { Quantity } \\
6\end{array}$ & $\begin{array}{c}\text { Quantity } \\
7.5\end{array}$ \\
\hline Soft wheat & -0.4 & -0.6 & -0.8 & -0.6 & -0.9 & -1.2 & +1.5 & +2.2 & +2.8 & -0.1 & -0.2 & -0.3 \\
\hline Barley & -0.8 & -1.1 & -1.4 & -0.4 & -0.8 & -1.1 & -20.5 & -18.8 & -17.5 & -0.8 & -1.0 & -1.1 \\
\hline Rape & -1.8 & -0.5 & +0.5 & -2.4 & -0.6 & 0.9 & +4.7 & +0.1 & -3.4 & -1.3 & -0.1 & +0.8 \\
\hline Rape oil & -2.7 & -0.7 & +1.0 & -5.4 & -0.6 & +3.1 & +3.3 & -0.7 & -3.6 & -1.5 & +0.1 & +1.3 \\
\hline Rape meal & -2.7 & -0.7 & +1.0 & -2.4 & -1.1 & 0 & -7.6 & +5.1 & +15.2 & +0.8 & -1.3 & -2.8 \\
\hline Bovine meat & -1.2 & -2.1 & -2.8 & -1.1 & -2.0 & -2.6 & n.s. & n.s. & n.s. & +2.1 & +2.8 & +3.3 \\
\hline Poultry meat & -1.3 & -1.3 & -1.4 & +1.5 & +1.4 & +1.3 & -48.6 & -48.4 & -48.3 & -1.3 & -1.4 & -1.5 \\
\hline Pig meat & -0.2 & -0.2 & -0.2 & +0.8 & +0.8 & +0.7 & -26.8 & -26.6 & -26.4 & 0 & 0 & -0.1 \\
\hline Milk & -3.8 & -6.0 & -7.5 & -3.8 & -6.0 & -7.5 & n.s. & n.s. & n.s. & -17.3 & -1.8 & +11.0 \\
\hline Butter & -4.6 & -8.6 & -11.1 & +4.2 & +0.5 & -2.0 & -92.6 & -98.9 & -99.7 & -19.3 & -2.3 & +12.6 \\
\hline Skimmed milk powder & -5.7 & -11.1 & -14.2 & +1.9 & +0.7 & -0.2 & -30.2 & -48.4 & -58.6 & -7.8 & -4.9 & -2.8 \\
\hline Cheese & -2.4 & -5.0 & -7.0 & +2.6 & +0.5 & -1.2 & -55.3 & -62.9 & -67.9 & -5.9 & -1.0 & +3.0 \\
\hline Other dairy products & -4.6 & -4.9 & -5.1 & -0.3 & -0.3 & -0.3 & -66.0 & -70.5 & -73.6 & -4.6 & -0.5 & +2.8 \\
\hline
\end{tabular}

n.s.: non significant

*: Composite price of domestic price of exports and domestic price of goods sold on the domestic market 
Table 8. Welfare impacts of two management schemes of the phasing out of agricultural export subsidies (Differences from the reference situation)

\begin{tabular}{|c|c|c|c|c|c|c|}
\hline & \multicolumn{2}{|c|}{ Price management } & \multicolumn{2}{|c|}{ Quantity management 6\% } & \multicolumn{2}{|c|}{ Quantity management $7.5 \%$} \\
\hline & Millions euros & $\%$ & Millions euros & $\%$ & Millions euros & $\%$ \\
\hline Arable crop complex & -239 & -0.9 & -249 & -0.9 & -250 & -0.9 \\
\hline Arable crop farming & -109 & -0.6 & -78 & -0.4 & -51 & -0.3 \\
\hline Cereal processing industry & -26 & -0.7 & -42 & -1.2 & -55 & -1.6 \\
\hline Oilseed crushing industry & -20 & -4.0 & -11 & -2.2 & -3 & -0.7 \\
\hline Compound feed industry & -84 & -2.2 & -118 & -3.1 & -141 & -3.7 \\
\hline Dairy complex & -4695 & -14.3 & -663 & -2.0 & +2524 & +7.7 \\
\hline Milk farming & -3890 & -23.5 & +394 & +2.4 & +3759 & +22.7 \\
\hline Dairy industry & -805 & -4.9 & -1058 & -6.5 & -1235 & -7.7 \\
\hline Meat complex & -122 & -0.4 & -234 & -0.7 & -318 & -1.0 \\
\hline Ruminant farming & +114 & +0.7 & +90 & +0.5 & +72 & +0.4 \\
\hline Non ruminant farming & -68 & -0.7 & +77 & +0.7 & +178 & +1.7 \\
\hline Meat industry & -236 & -1.6 & -324 & -2.2 & -391 & -2.6 \\
\hline Sugar complex & -14 & -0.2 & -10 & -0.2 & -6 & -0.1 \\
\hline Sugar beet farming & +18 & +0.6 & +38 & +1.3 & +54 & +1.8 \\
\hline Sugar beet industry & -33 & -1.0 & -49 & -1.5 & -60 & -1.8 \\
\hline Agribusiness & -5139 & -4.7 & -1080 & -1.0 & +2128 & +2.0 \\
\hline Agriculture & -3935 & -5.9 & +522 & +0.8 & +4013 & +6.1 \\
\hline Food processing & -1204 & -2.8 & -1603 & -3.8 & -1885 & -4.5 \\
\hline EU Welfare & +2652 & & +2333 & & +2011 & \\
\hline
\end{tabular}

The welfare of producing sectors is measured by their value added. The EU Welfare is measured by the Equivalent Variation. 
Table 9. Sensitivity of welfare effects to world market conditions (Differences from the reference situations in millions euros; in parentheses, percentage changes)

\begin{tabular}{|c|c|c|c|c|c|c|}
\hline \multirow{2}{*}{$\begin{array}{l}\text { World market conditions } \\
\text { Management }\end{array}$} & \multicolumn{2}{|c|}{ Base plus $10 \%$} & \multicolumn{2}{|c|}{ Base } & \multicolumn{2}{|c|}{ Base minus $10 \%$} \\
\hline & Price & Quantity 6 & Price & Quantity 6 & Price & Quantity 6 \\
\hline \multirow[t]{2}{*}{ Agriculture } & -4071 & +2406 & -3935 & +522 & -4128 & -1238 \\
\hline & $(-5.9)$ & $(+3.5)$ & $(-5.9)$ & $(+0.8)$ & $(-6.3)$ & $(-1.9)$ \\
\hline \multirow[t]{2}{*}{ Food processing } & -738 & -1378 & -1204 & -1603 & -1524 & -1764 \\
\hline & $(-1.7)$ & $(-3.2)$ & $(-2.8)$ & $(-3.8)$ & $(-3.6)$ & $(-4.2)$ \\
\hline \multirow[t]{2}{*}{ Agribusiness } & -4809 & +1027 & -5139 & -1080 & -5652 & -3003 \\
\hline & $(-4.3)$ & $(+0.9)$ & $(-4.7)$ & $(-1.0)$ & $(-5.3)$ & $(-2.8)$ \\
\hline EU Welfare & 2048 & +1695 & +2652 & +2333 & +3116 & +2876 \\
\hline
\end{tabular}

The welfare of producing sectors is measured by their value added. The EU Welfare is measured by the Equivalent Variation. 


\section{Working Papers INRA - Unité ESR Rennes}

02-01 Tariff protection elimination and Common Agricultural Policy reform: Implications of changes in methods of import demand modelling. Alexandre GOHIN, Hervé GUYOMARD, Chantal LE MOUËL (March 2002)

02-02 Reducing farm credit rationing: An assessment of the relative effectiveness of two government intervention schemes. Laure LATRUFFE, Rob FRASER (April 2002)

02-03 Farm credit rationing and government intervention in Poland. Laure LATRUFFE, Rob FRASER (May 2002)

02-04 The New Banana Import Regime in the European Union: A Quantitative Assessment. Hervé GUYOMARD, Chantal LE MOUËL (July 2002)

02-05 Determinants of technical efficiency of crop and livestock farms in Poland. Laure LATRUFFE, Kelvin BALCOMBE, Sophia DAVIDOVA, Katarzyna ZAWALINSKA (August 2002)

02-06 Technical and scale efficiency of crop and livestock farms in Poland: Does specialisation matter? Laure LATRUFFE, Kelvin BALCOMBE, Sophia DAVIDOVA, and Katarzyna ZAWALINSKA (October 2002)

03-01 La mesure du pouvoir de vote. Nicolas-Gabriel ANDJIGA, Frédéric CHANTREUIL, Dominique LEPELLEY (January 2003)

03-02 Les exploitations agricoles polonaises à la veille de l'élargissement : structure économique et financière. Laure LATRUFFE (March 2003) 
03-03 The Specification of Price and Income Elasticities in Computable General Equilibrium Models: An Application of Latent Separability. Alexandre GOHIN (April 2003)

03-04 Mesures agro-environnementales et demande de travail agricole. Pierre DUPRAZ (May 2003)

03-05 The Fischler's Proposals for the Common Agricultural Policy: Paving the Way for the Future? Hervé GUYOMARD, Katell LE BRIS (June 2003)

03-06 The phasing out of EU agricultural export subsidies: Impacts of two management schemes. Alexandre GOHIN, Patrice GAUTIER (June 2003) 